\title{
Population size and trend, and habitat selection of Common Moorhens Gallinula chloropus in Oslo and Akershus, southeastern Norway
}

\section{Svein Dale}

Faculty of Environmental Sciences and Natural Resource Management, Norwegian University of Life Sciences, P.O.Box 5003, NO-1432 Ås, Norway. Correspondence; e-mail: svein.dale@nmbu.no

\begin{abstract}
The Common Moorhen Gallinula chloropus is listed as vulnerable (VU) in Norway due to a small population size (estimated at 110-215 pairs in 2015). The population size is considered stable. More than one quarter of the population (30-70 pairs) is thought to occur in the region of Oslo and Akershus, SE Norway. In 2018, I conducted a comprehensive survey of known and potential breeding sites to assess current population size in Oslo and Akershus. I recorded 74 pairs in 58 sites. To analyse the population trend, I collected all known records of Common Moorhen during the breeding season for the period 1995-2018. Analyses indicated that population size was stable overall. However, compared to data from 1982, sites with the largest number of pairs in 1982 have had declining population size, and these sites also had high nutrient levels. On the other hand, several new breeding sites in recently created ponds in parks, on golf courses and wastewater treatment plants have been established. Dammed ponds were occupied more often than natural waterbodies, and occupied sites were in general at nutrient-rich sites at low elevation close to the coast. Occupancy rate (proportion of years surveyed with Common Moorhen presence) during 1995-2018 was higher for dammed ponds than for natural waterbodies, and higher for smaller wetlands. Thus, analyses suggested that the most suitable sites for Common Moorhen were nutrient-rich small ponds at low elevation close to the coast, and in such sites the Common Moorhen appears to have a stable, but small population size.
\end{abstract}

Keywords: Common Moorhen, habitat selection, population size, population trend, red listing

\section{INTRODUCTION}

The Common Moorhen Gallinula chloropus (hereafter Moorhen) is listed as vulnerable (VU) on the Norwegian red list (Kålås et al. 2015) due to a small population size $(<1000$ reproducing individuals). The population size in Norway has recently been estimated at 110-215 pairs and is considered to be stable (Shimmings \& Øien 2015). Previous estimates have been highly divergent, with 500-2000 pairs estimated by Gjershaug et al. (1994), and 100-200 pairs by Anfinnsen (1961).

Oslo and Akershus in southeastern Norway have important breeding sites for the Moorhen (Dale et al. 2001). More than one quarter of the Norwegian population has been estimated to occur here (30-70 pairs; Shimmings \& Øien 2015). A previous estimate of population size in Oslo and Akershus, based on data from around 1980, indicated 50-60 pairs (Olsen 1982). However, none of the previous population estimates presented for Norway or for specific counties have been based on systematic surveys of all potential breeding sites for Moorhens.

In Norway, the Moorhen is distributed along the southern coast, in particular around the Oslofjord, and is reported to prefer small, nutrient-rich and vegetationrich wetlands in the lowlands (Anfinnsen 1961, Haftorn 1971, Øien 1994, Dale et al. 2001). However, these habitat preferences have not been documented with quantitative analyses.

In the present study, I conducted a comprehensive survey of known and potential breeding sites to assess current population size in Oslo and Akershus. I also analysed changes in population size in the region compared to Olsen (1982), and also during the period 1995-2018. Furthermore, I analysed habitat selection in Oslo and Akershus. Based on previous information I predicted that Moorhens should be present in particular at small and nutrient-rich wetlands at low elevation close to the coast, and that such sites should also have a high occupancy rate (proportion of years surveyed with Moorhen presence).

\section{METHODS}

\section{Study area and field survey in 2018}

During 27 April-22 June 2018 I surveyed nearly all potential sites in Oslo and Akershus counties for breeding Moorhens (Akershus was in 2020 included in the new Viken county together with former counties Østfold and Buskerud). These included all known breeding sites based on Olsen (1982), Dale et al. (2001), own observations thereafter, and reports submitted to 
the websites of the Norwegian Ornithological Society, Oslo and Akershus branch (www.nofoa.no) and the Norwegian Biodiversity Information Centre (www. artsobservasjoner.no). All known sites were in the lowlands ( $<220 \mathrm{~m}$ a.s.1.). In addition, I surveyed many of other potential breeding sites in the lowlands of Oslo and Akershus.

Potential breeding sites for Moorhens were considered to be limited to the lowlands of Oslo and Akershus because nutrient-rich lakes and wetlands only occur below $220 \mathrm{~m}$ elevation. This is due to nutrient-rich glacial clay sediments that were deposited in marine environments at the end of the last glaciation when sea level was $220 \mathrm{~m}$ higher than at present in the study area. Above $220 \mathrm{~m}$ elevation there is mostly nutrient-poor moraine and lakes are generally oligotrophic (Økland \& Økland 1998). Most lakes and wetlands above $220 \mathrm{~m}$ elevation have been visited regularly in recent decades so that the absence of Moorhens from such sites has been confirmed by substantial field work. In the present study, investigating the effect of variation in elevation of sites below $220 \mathrm{~m}$ a.s.l. on Moorhen presence was an objective.

In total, 237 sites were surveyed (Figure 1). Each site was surveyed once for approximately 15-60 min depending on size. Surveys were done using binoculars, but for larger lakes a telescope $(25 \mathrm{x}-50 \mathrm{x})$ was also used. During surveys, I accessed viewpoints that together provided a complete or almost complete overview of each site. I counted the number of adult Moorhens present. Playback of Moorhen calls was used frequently. Due to the possibility that individuals, in particular during incubation, could be concealed by vegetation, single individuals were also considered to represent a pair or an occupied territory. Most sites were regarded to have one pair, but observations of three or more adult individuals in one site, or observations well separated by distance within a site were regarded to represent two or more pairs. Note, however, that I did not require direct evidence of actual breeding behaviour, so the data presented refer to birds present during the breeding season. Presence during 2018 was mainly based on results of own surveys, but for five sites own data were supplemented with reports from other sources (see next paragraph), and presence in two sites was only based on other sources.

\section{Historical data}

To assess changes in population size in detail, I collected historical records of Moorhens from the breeding season (April-August) in Oslo and Akershus. In addition to using own records, I searched the websites www.nofoa.no and www.artsobservasjoner. no, and published information (in particular in the journal Toppdykker'n published by the Norwegian
Ornithological Society, Oslo and Akershus branch). To be classified as present in a specific year, I required at least one positive record of Moorhen. However, additional visits without observations in the same year did not negate presence because Moorhens may behave secretively and avoid detection on single visits.

For all sites holding Moorhens during the breeding season in at least one year, I also searched published records for visits during the breeding season with no Moorhens observed (negative records) to establish whether the species could be recorded as absent in years when there were no positive records. Note that this method may overestimate absence because Moorhens may be overlooked at single visits. However, my own field work in 2018 showed that initial visual scanning of sites revealed the presence of Moorhens before any use of playback in 50 out of 52 sites.

Negative records were based on reports that included observations of at least one other wetland bird species. Reports that mainly included rare or extraordinary species were considered likely to have omitted sightings of Moorhens, and they were not included as negative records. However, if the reports included common wetland species, I considered it likely that any sightings of Moorhen would also have been included. Thus, if in such cases no Moorhens were reported, this was interpreted as absence, and included as a negative record. Because most lakes were relatively small and easy to survey, the number of individuals reported most likely represented good estimates of the total number of individuals present. In addition to sites with no records at all of Moorhens $(n=129)$, sites with only a few observations of single individuals or pairs during the breeding season, and where breeding has not been recorded were also classified as unoccupied ( $\mathrm{n}=26$ sites; 25 sites with only $1-3$ records, one site with irregular records of non-breeders). Out of all 237 sites, 82 were classified as breeding sites (occupied in at least one year), whereas 155 sites were classified as unoccupied.

\section{Analyses of population change}

I analysed population changes in Oslo and Akershus in two ways. First, I compared the number of pairs recorded in 2018 with that reported by Olsen (1982). Second, I analysed yearly population changes based on the historical data. The amount of data was limited for the earliest period, as has been found in similar analyses for other species in Oslo and Akershus (Monthouel \& Dale 2019). From 1995, more data were available due to the initiation of a project of systematic surveys of the bird communities all over Oslo and Akershus (see Dale et al. 2001). Thus, I only included data for the period 1995-2018. Analyses were done with the package rtrim version 2.0.6 (Bogaart et al. 2018). This is a program 


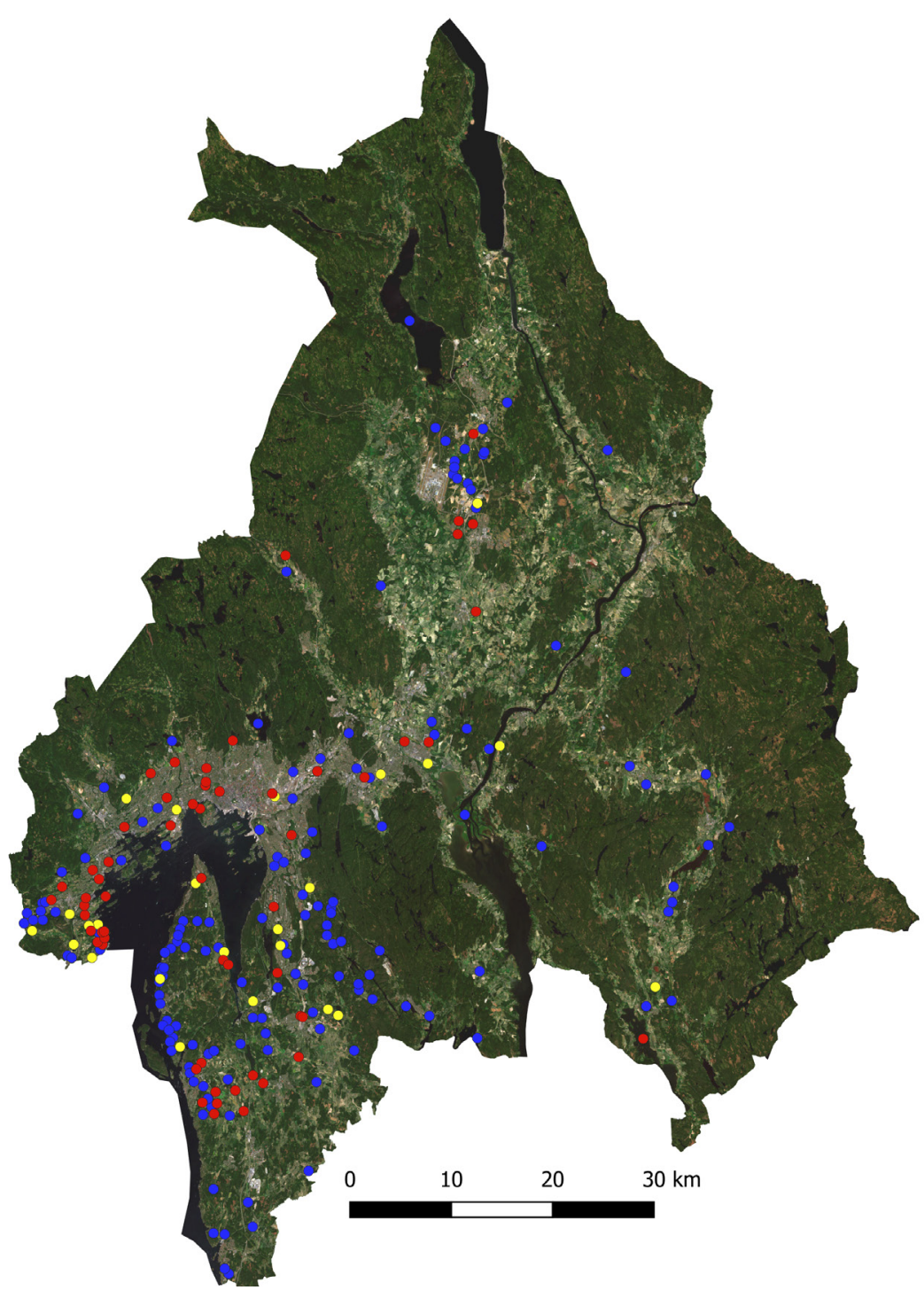

Figure 1. Distribution of breeding sites of Common Moorhens in Oslo and Akershus, southeastern Norway. Red dots: sites occupied in 2018. Yellow dots: sites occupied in other years. Blue dots: unoccupied sites (i.e. no confirmed breeding in any year).

for the analysis of time series of counts, using Poisson regression, and is particularly well suited for time series with missing observations for time points. Analyses were performed using model 2 which assumes that populations vary across sites but show the same growth everywhere and that growth rates are constant during specified time intervals.

\section{Habitat selection and analyses}

All surveyed sites were classified as belonging to one of seven different habitats (Table 1; see e.g. www. asker.kommune.no/vann-og-avlop/dammer-i-asker/ for photographic examples): 1) Natural waterbodies included lakes, ponds and other wetlands without dams, 2) farm ponds were small waterbodies dammed to provide water for agricultural irrigation, 3) park ponds were dammed waterbodies made for aesthetical purposes in parks, 4) golf course ponds were artificial waterbodies located within golf courses, 5) ice ponds were dammed waterbodies originally made to cut ice during winter for commercial purposes (see no.wikipedia.org/wiki/Isdrift), but none are used for that today, 6) filtering ponds were artificial waterbodies made to clean wastewater, and 7) all other ponds were dammed waterbodies made for other purposes or for which the purpose was unknown.

To assess habitat preferences, I used a contingency table analysis to compare the number of occupied sites with the number of sites that have not been occupied by Moorhens. This analysis included all habitat types except filtering ponds (only two sites known). To assess which habitats were used more or less often than expected, I compared the $\chi^{2}$-contributions of individual habitats (determined by the differences between observed and expected values) to the total $\chi^{2}$ in the analysis (Siegel \& Castellan 1988). 
Table 1. Habitat selection of Common Moorhens in Oslo and Akershus, southeastern Norway, and habitat-specific occupancy rates. Note that all habitat types, except natural waterbodies, were ponds that have been artificially created by damming.

\begin{tabular}{|c|c|c|c|c|c|}
\hline \multirow[b]{2}{*}{ Habitat $^{1}$} & \multirow{2}{*}{$\begin{array}{l}\text { Total no. } \\
\text { of sites } \\
\text { surveyed } \\
\text { in } 2018\end{array}$} & \multirow{2}{*}{$\begin{array}{c}\text { Total no. } \\
\text { of sites } \\
\text { occupied } \\
\text { 1995-2018 }\end{array}$} & \multirow{2}{*}{$\begin{array}{c}\text { Pairs } \\
2018\end{array}$} & \multicolumn{2}{|c|}{ Occupancy rate ${ }^{2}$} \\
\hline & & & & Mean & SE \\
\hline Natural waterbodies & 113 & 26 & 25 & 0.36 & 0.05 \\
\hline Farm pond & 20 & 8 & 10 & 0.75 & 0.10 \\
\hline Park pond & 17 & 10 & 11 & 0.67 & 0.10 \\
\hline Golf course pond & 8 & 4 & 5 & 0.52 & 0.14 \\
\hline Ice pond & 54 & 24 & 17 & 0.63 & 0.05 \\
\hline Filtering pond & 2 & 2 & 3 & 0.64 & 0.14 \\
\hline Other types of ponds & 23 & 6 & 3 & 0.39 & 0.10 \\
\hline Total & 237 & $80^{3}$ & 74 & 0.54 & 0.03 \\
\hline
\end{tabular}

\footnotetext{
${ }^{1}$ See Methods for details

${ }^{2}$ Proportion of years surveyed during 1995-2018 with Common Moorhens present. Including only sites surveyed in at least 3 years $(n=79)$ for specific habitats

${ }^{3}$ Total number of occupied sites were 82 , but two sites were only occupied before 1995 . One of these two sites was surveyed repeatedly during 1995-2018 and was included in analyses of occupancy rate (occupancy rate $=0$ )
}

Occupancy rate was used as a measure of how suitable breeding sites have been for Moorhens. Occupancy rate was defined as the proportion of the total number of years a site has been surveyed during 1995-2018 in which Moorhens were present. Occupancy rate was calculated for all occupied sites with at least three years of data (range 3-24 years, mean $=13.6, \mathrm{n}=79$ ). I used a one-way ANOVA to investigate if occupancy rate differed between habitats, and significant post-hoc differences between individual habitats were identified with Fishers LSD tests. Note that one site had an occupancy rate of zero (no records during 1995-2018), but was included because it was defined as an occupied site (Moorhens were present earlier than 1995).

To assess temporal changes in availability of breeding sites with different habitat types, I compared aerial photographs from www.norgeibilder.no taken at different times to identify when wetlands were created or disappeared. In addition, I used other relevant websites to obtain information on when dammed ponds were created, e.g. websites of golf clubs indicating when a golf course was constructed.

\section{Site variables and analyses}

I measured wetland size, elevation and distance from the coast (shortest distance to the Oslofjord) for all 237 sites by using www.norgeskart.no. Data on nutrient level (phosphorus level measured as $\mu \mathrm{g} / \mathrm{P} / \mathrm{l}$ ) were taken from the water environment website of the
Norwegian Environment Agency (www.vannmiljo. miljodirektoratet.no) and included 31 occupied sites and 46 unoccupied sites. I retrieved 3139 individual phosphorus sample measurements from April-October during 1995-2018. Mean phosphorus levels of the 77 sites were estimated from a GLM with year and date of samples as covariates and site as a fixed factor.

Initial analyses of how occupancy (occupied versus not occupied) of sites was related to the four site variables were conducted with Mann-Whitney U-tests due to non-normal distribution of variables (Siegel \& Castellan 1988). Further, I used logistic regressions to assess the relative importance of site variables. One analysis included all four site variables (wetland size, elevation, distance from the coast, nutrient level) as explanatory variables in the logistic regression, but because data on nutrient level were unavailable for many sites this analysis was restricted to 77 sites. Another analysis used only the three variables (wetland size, elevation and distance from the coast) for which there were data from all 237 sites. Wetland size, distance from coast and nutrient level were logtransformed prior to analyses. For both analyses, full models are presented together with reduced (final) models after stepwise backwards elimination of nonsignificant variables.

Occupancy rate was initially analysed in relation to the four site variables with Spearman rank correlations (Siegel \& Castellan 1988). Next, I conducted GLM analyses to assess the relative importance of site variables, one including all four site variables $(n=31)$, and another including only wetland size, elevation and 
Table 2. Comparison of Common Moorhen population estimates for Oslo and Akershus, southeastern Norway, from 1982 (Olsen 1982) and survey results from 2018.

\begin{tabular}{lcc}
\hline Municipality $^{1}$ & Pairs 1982 & Pairs 2018 \\
\hline Asker & 5 & 16 \\
Bærum & $3-5$ & 7 \\
Oslo & $20-21$ & 18 \\
Nesodden & 0 & 3 \\
Oppegård, Ås and Frogn & $4-7$ & 17 \\
Ski & $2-4$ & 3 \\
Lørenskog & 0 & 1 \\
Skedsmo & 2 & 2 \\
Nittedal & 0 & 1 \\
Ullensaker & 0 & 5 \\
Aurskog-Høland & $12-13$ & 1 \\
\hline Total number of pairs & $50-60^{2}$ & 74 \\
Number of sites & 16 & 58 \\
\hline
\end{tabular}

${ }^{1}$ Following municipality structure before the 2020 reform

${ }^{2}$ Exact figures were 48-57

distance from the coast as explanatory variables $(\mathrm{n}=$ 79). Wetland size, distance from coast and nutrient level were log-transformed prior to analyses. For both analyses, full models are presented together with reduced (final) models after stepwise backwards elimination of non-significant variables. Models were checked for outliers and normality of residuals, but no departures were found. GLM and logistic regression analyses were done with JMP version 15 .

\section{RESULTS}

\section{Population size and population changes}

In 2018, 74 pairs of Moorhens were recorded in 58 sites in Oslo and Akershus (Tables $1 \& 2$, Figure 1). Compared to an estimated population size of 50-60 pairs at 16 sites in 1982 (Table 2), this represented a $23-48 \%$ increase in the number of pairs and a $263 \%$ increase in the number of sites. However, during the period 1995-2018, the rtrim-analysis classified the population as stable (yearly rate of change: $0.82 \%$, SE $=0.50, \mathrm{p}=0.11$, Figure 2). Between 1982 and 2018, population change was negatively related to the number of pairs individual sites had in $1982\left(\mathrm{r}_{\mathrm{s}}=-0.85, \mathrm{n}=19\right.$, $\mathrm{p}<0.001$; Figure 3).

\section{Selection of habitat types}

Moorhens used a wide variety of wetland types (Table

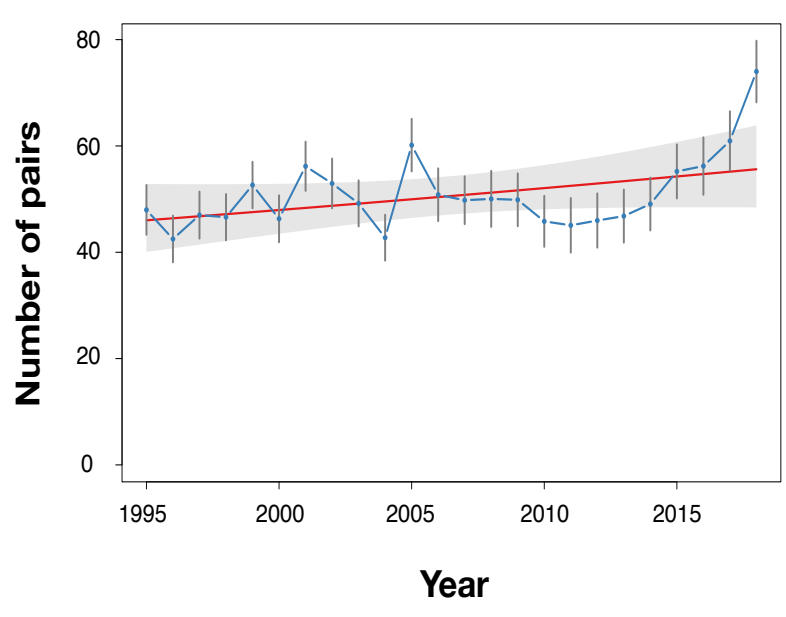

Figure 2. Estimated population size of Common Moorhens in Oslo and Akershus, southeastern Norway, during 1995-2018 (rtrim-analysis). Red line: overall population trend (shaded area shows $95 \%$ confidence interval). Blue line: estimated population size for each year (with SE error bars).

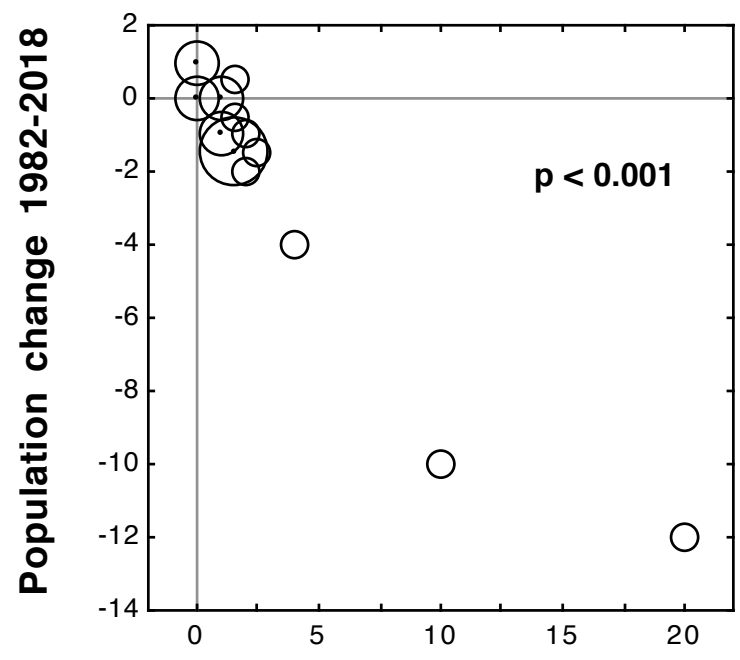

\section{Population size in 1982}

Figure 3. Population change of Common Moorhens in Oslo and Akershus, southeastern Norway, during 1982-2018 in relation to population size in 1982. Data points represent individual sites. Data for 1982 were from Olsen (1982). Overlapping data points are indicated by larger symbols. $\mathrm{P}$-value of Spearman rank correlation is shown (see main text for details).

1). However, proportional use was significantly different from random $\left(\chi^{2}=13.44, \mathrm{df}=5, \mathrm{p}=0.02\right.$; comparing 80 occupied sites with 155 unoccupied sites; filtering ponds excluded). Natural waterbodies were occupied less often than expected, whereas park ponds and ice ponds were occupied more often than expected (these three habitat types had the largest $\chi^{2}$-contributions, $\chi^{2}=$ 11.57 in total).

Occupancy rates also varied in relation to habitat $(\mathrm{F}=3.87, \mathrm{df}=6, \mathrm{p}=0.002$; Table 1$)$. Farm ponds had an occupancy rate significantly higher than both natural 
Table 3. Logistic regression analysis of factors related to occupancy (occupied sites versus unoccupied sites) of Common Moorhens in Oslo and Akershus, southeastern Norway. The limited data set only included sites for which data on nutrient level were available. The reduced (final) models show results after stepwise backwards elimination of non-significant variables from the full model.

\begin{tabular}{|c|c|c|c|c|c|}
\hline Variable & $\begin{array}{c}\text { Full model } \\
\text { Estimate }\end{array}$ & SE & $\chi^{2}$ & $\mathbf{p}$ & $\begin{array}{c}\text { Reduced model } \\
\mathbf{p}\end{array}$ \\
\hline All sites $(\mathrm{n}=237)$ & $r^{2}=0.06$ & & & & $r^{2}=0.06$ \\
\hline Wetland size ${ }^{1}$ & -0.046 & 0.189 & 0.06 & 0.81 & \\
\hline Distance from coast ${ }^{1}$ & -0.312 & 0.321 & 0.94 & 0.33 & \\
\hline Elevation & 0.015 & 0.005 & 10.34 & 0.001 & $<0.001$ \\
\hline Limited data set $(n=77)$ & $\mathrm{r}^{2}=0.15$ & & & & $\mathrm{r}^{2}=0.13$ \\
\hline Wetland size ${ }^{1}$ & -0.397 & 0.378 & 1.10 & 0.29 & \\
\hline Distance from coast ${ }^{1}$ & 1.040 & 0.680 & 2.34 & 0.13 & 0.010 \\
\hline Elevation & 0.002 & 0.008 & 0.05 & 0.82 & \\
\hline Nutrient level $^{1}$ & -2.271 & 1.125 & 4.08 & 0.044 & 0.014 \\
\hline
\end{tabular}

${ }^{1}$ Log-transformed

Table 4. GLM of factors related to occupancy rate of Common Moorhens (proportion of years surveyed with presence during 1995-2018) in Oslo and Akershus, southeastern Norway. The limited data set only included sites for which data on nutrient level were available. The reduced (final) models show results after stepwise backwards elimination of non-significant variables from the full model.

\begin{tabular}{|c|c|c|c|c|c|}
\hline Variable & $\begin{array}{c}\text { Full model } \\
\text { Estimate }\end{array}$ & SE & $\mathbf{t}$ & $\mathbf{p}$ & $\begin{array}{c}\text { Reduced model } \\
\mathbf{p}\end{array}$ \\
\hline All sites $(\mathrm{n}=79)$ & $\mathrm{r}^{2}=0.15$ & & & & $\mathrm{r}^{2}=0.14$ \\
\hline Wetland size ${ }^{1}$ & -0.098 & 0.042 & -2.36 & 0.021 & 0.029 \\
\hline Distance from coast ${ }^{1}$ & 0.064 & 0.080 & 0.81 & 0.42 & \\
\hline Elevation & -0.002 & 0.001 & -1.75 & 0.084 & 0.054 \\
\hline Limited data set $(\mathrm{n}=31)$ & $r^{2}=0.29$ & & & & $\mathrm{r}^{2}=0.10$ \\
\hline Wetland size ${ }^{1}$ & -0.172 & 0.079 & -2.17 & 0.039 & 0.004 \\
\hline Distance from coast ${ }^{1}$ & 0.010 & 0.152 & 0.66 & 0.52 & \\
\hline Elevation & -0.002 & 0.002 & -1.22 & 0.23 & \\
\hline Nutrient level ${ }^{1}$ & 0.149 & 0.179 & 0.83 & 0.41 & \\
\hline
\end{tabular}

\footnotetext{
${ }^{1}$ Log-transformed
}

waterbodies and the category, other types of dammed ponds', and park ponds and ice ponds had a higher occupancy rate than natural waterbodies (significant post-hoc comparisons with Fisher's LSD test).

\section{Temporal changes in habitat availability}

Golf course ponds and filtering ponds were new habitats for Moorhens in Oslo and Akershus compared to 1982. The four golf course pond sites occupied were created during 2001-2005. The two filtering pond sites were created in 2007 and ca. 2005, respectively. In addition, one new pond in an urban park was created in 2015. Moreover, one natural pond dried out around 1999, and two dammed ponds (one ice pond and one other type of dammed pond) were temporarily empty during 2017 2018 and 2001-2008, respectively.

\section{Site use in relation to site variables}

Occupied sites were closer to the coast (Mann-Whitney U-test: $\mathrm{U}=4951, \mathrm{p}=0.005)$, at lower elevation ( $\mathrm{U}=$ 

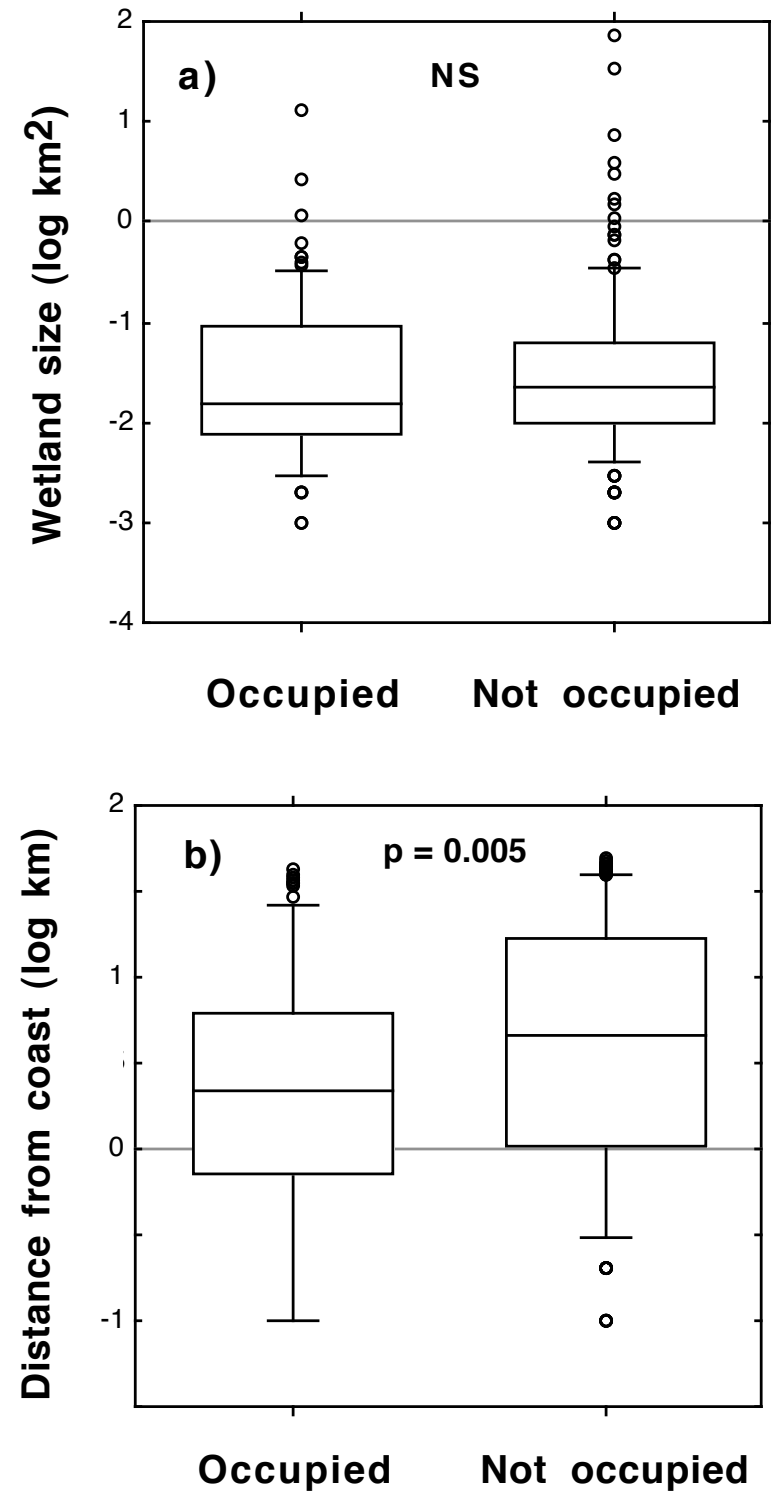
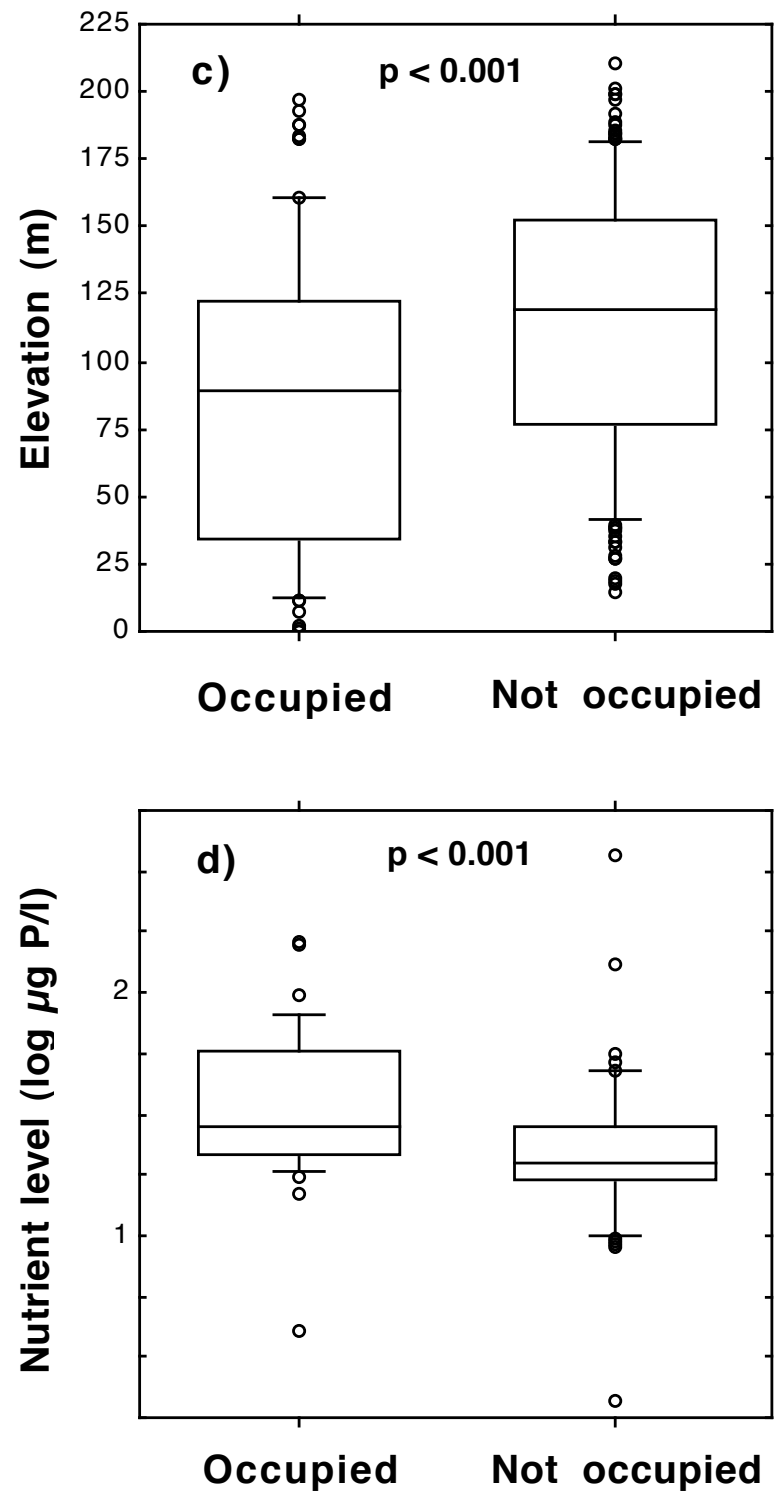

Figure 4. Boxplots of a) wetland size, b) distance from coast, c) elevation and d) nutrient level for sites occupied and not occupied by Common Moorhens in Oslo and Akershus, southeastern Norway. Sample size was 82 occupied sites and 155 unoccupied sites, except for nutrient level where data were missing for some sites (sample size used was 30 occupied sites and 46 unoccupied sites). P-values of Mann-Whitney U-tests are shown (see main text for details). NS = not significant.

4306, $\mathrm{p}<0.001$ ), and had a higher nutrient level (U $=388, \mathrm{p}<0.001$; Figure 4) than unoccupied sites. However, there was no difference between occupied and unoccupied sites regarding wetland size $(\mathrm{U}=$ 5794, $\mathrm{p}=0.26$; Figure 4). A logistic regression analysis with wetland size, distance from coast and elevation as explanatory variables, and occupancy as response variable indicated that occupied sites were at lower elevations than unoccupied sites (Table 3). However, a logistic regression analysis of a reduced sample size for which data on nutrient level were also available indicated that occupied sites were closer to the coast and had higher nutrient levels than unoccupied sites (Table 3).
Occupancy rate for the occupied sites declined with both wetland size $\left(\mathrm{r}_{\mathrm{s}}=-0.29, \mathrm{n}=79, \mathrm{p}=0.011\right)$, distance from the coast $\left(\mathrm{r}_{\mathrm{s}}=-0.26, \mathrm{n}=79, \mathrm{p}=0.022\right)$, and elevation $\left(r_{s}=-0.31, n=79, p=0.007\right)$, but was not related to nutrient level $\left(r_{\mathrm{s}}=0.21, \mathrm{n}=31, \mathrm{p}\right.$ $=0.24$, Figure 5). A GLM with the three former site variables as explanatory variables and occupancy rate as response variable indicated that occupancy rate declined with wetland size (Table 4), and there was a nearly significant trend that occupancy rate declined with elevation (Table 4). A GLM of a reduced sample size for which data on nutrient level were also available indicated that only wetland size was significant (Table 4). 

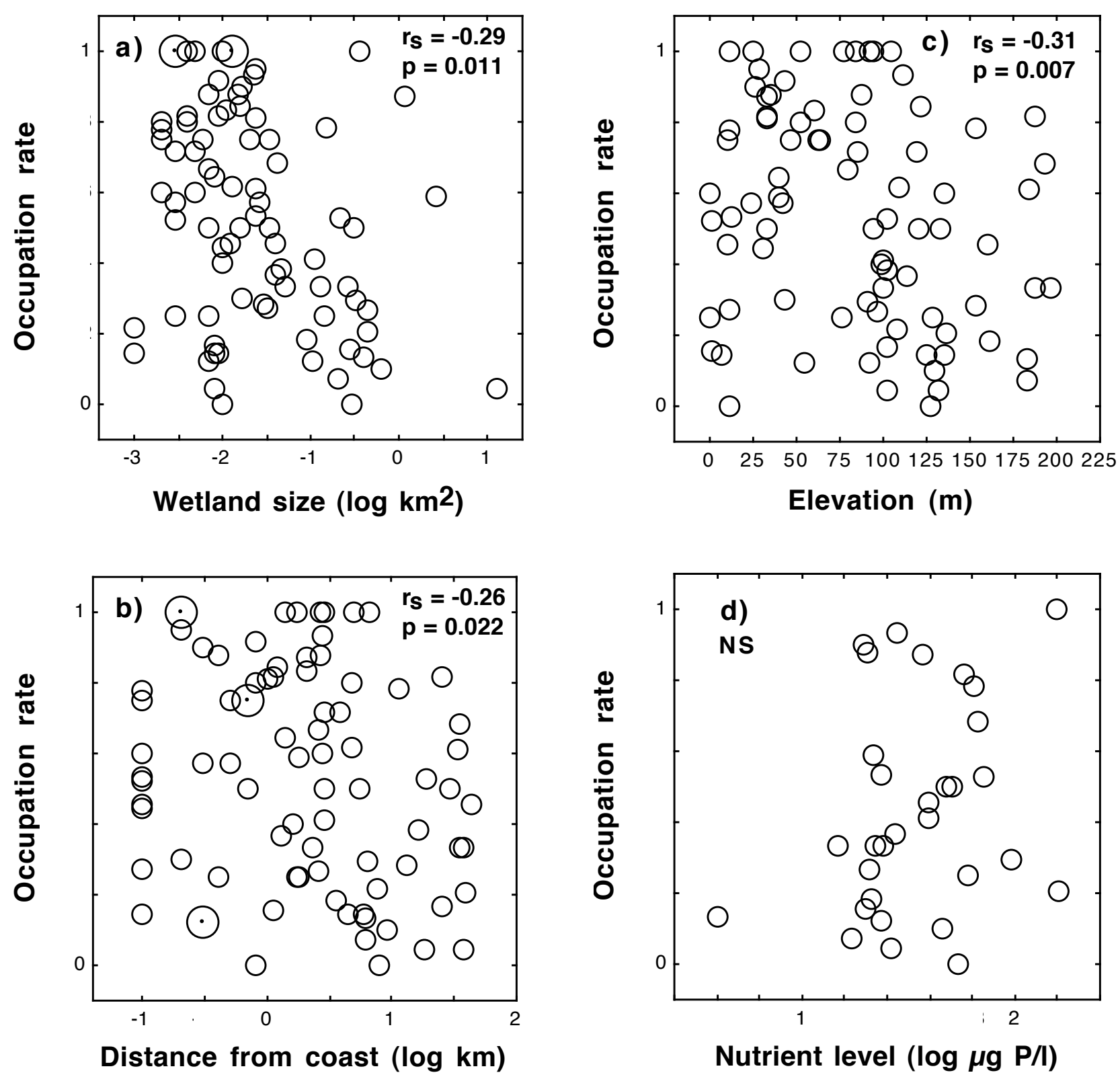

Figure 5. Occupancy rate of Common Moorhens (proportion of years surveyed with presence during 1995-2018) in Oslo and Akershus, southeastern Norway, in relation to a) wetland size, b) distance from coast, c) elevation and d) nutrient level. Sample size was 79 sites, except for nutrient level where data were missing for some sites (sample size used was 31). Overlapping data points are indicated by larger symbols. Correlation coefficients and p-values of Spearman rank correlations are shown (see main text for details). NS = not significant.

\section{Population changes and habitat characteristics}

Population change between 1982 and 2018 was not related to habitat type (ANOVA: $\mathrm{F}=1.49, \mathrm{df}=2, \mathrm{p}=$ 0.26 ; 13 sites were natural waterbodies, 3 park ponds, 3 ice ponds). However, population change during this period was related to distance from the coast $(r=-0.63$, $\mathrm{n}=19, \mathrm{p}=0.008)$ and elevation $\left(\mathrm{r}_{\mathrm{s}}=-0.57, \mathrm{n}=19, \mathrm{p}=\right.$ 0.016; Figure 6), such that sites furthest from the coast and at higher elevations declined the most. However, there were no significant relationships with wetland size $\left(r_{s}=-0.26, n=19, p=0.27\right)$ or nutrient level $\left(r_{s}=-0.38\right.$, $\mathrm{n}=13, \mathrm{p}=0.19$; Figure 6). However, a GLM with the three former site variables as explanatory variables and population change as response variable did not indicate any significant relationships (data not shown). A GLM of a reduced sample size for which data on nutrient level were also available $(\mathrm{n}=13)$ indicated that nutrient level had a significant effect with sites with the highest nutrient level declining the most $(p=0.006)$. 

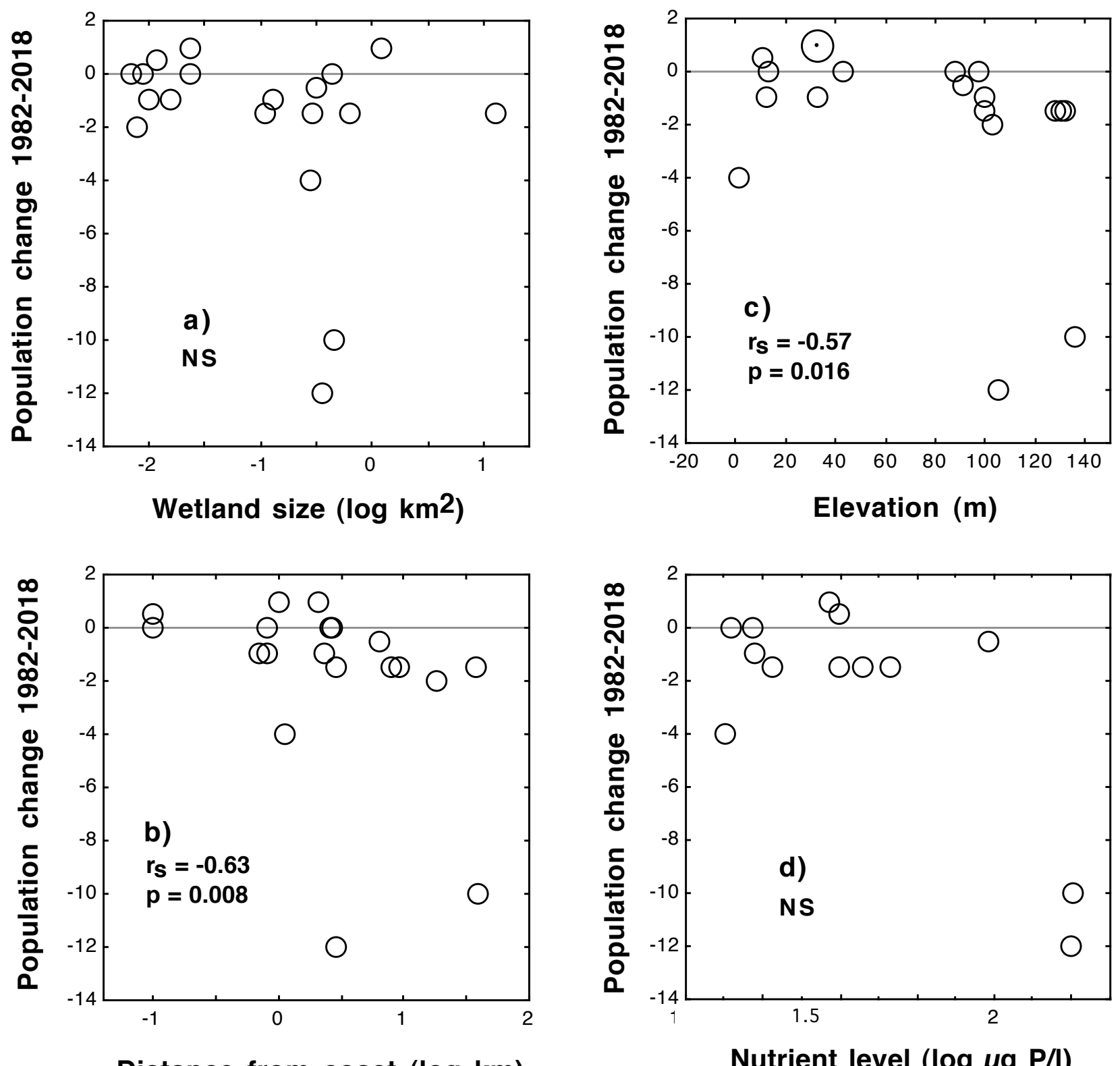

Distance from coast (log $\mathrm{km})$

Figure 6. Population change of Common Moorhens in Oslo and Akershus counties, southeastern Norway, during $1982-2018$ in relation to a) wetland size, b) distance from coast, c) elevation and d) nutrient level. Sample size was 19 sites, except for nutrient level where data were missing for some sites (sample size used was 13). Overlapping data points are indicated by larger symbols. Correlation coefficients and $p$-values of Spearman rank correlations are shown (see main text for details). NS $=$ not significant.

\section{DISCUSSION}

\section{Population size and trend}

In 2018, 74 pairs of Moorhen were recorded in Oslo and Akershus. This was somewhat higher than the previous estimates of 50-60 pairs (Olsen 1982) and 30-70 pairs (Shimmings \& Øien 2015). However, the population size was stable during the period 1995-2018 (note that the apparent increase in 2018 is likely due to a more thorough survey in that year). This may suggest that the previous estimates were not comprehensive, probably because some sites were not known previously, in particular not around 1980. Given that a previous review indicated that about one quarter of the Norwegian Moorhen population occurred in Oslo and Akershus (Shimmings \& Øien 2015), it appears that the national population size estimate of 500-2000 pairs reported by Gjershaug et al. (1994) must have been grossly overestimated, at least the upper limit. On the other hand, the other previous estimates (100-200 pairs by Anfinnsen 1961 and 110-215 pairs by Shimmings \& Øien 2015), in particular the latter, may be somewhat underestimated when Oslo and Akershus alone have 
74 pairs today. If the Oslo and Akershus region holds about one quarter of the Norwegian population, total population size in Norway may be around 300 pairs.

Although total population size of Moorhens in Oslo and Akershus was stable, there were some significant local population changes. Of the sites known by Olsen (1982), those with the largest number of pairs in 1982 have had the largest declines in population size. In particular, Østensjøvannet in Oslo now generally holds around 10 pairs whereas 20 pairs were estimated by Olsen (1982), and at Hellesjøvannet in AurskogHøland the Moorhen has been absent in most years during 1995-2018 compared to 10 pairs estimated by Olsen (1982). There were indications that declines were related to nutrient level, and one possible hypothesis is that some of the sites which were most polluted by sewage or nutrient run-off from surrounding farmland during the 1980's now have lower nutrient levels, and have therefore become less attractive to Moorhens. On the other hand, ponds at golf courses and filtering ponds are new suitable habitats for Moorhens in Oslo and Akershus, and six such sites were created during 2001-2007. One additional site for Moorhen was discovered in 2020 on a golf course. Thus, the decline in some sites has been more or less compensated for by creation of suitable new habitat in other places.

\section{Habitat selection}

Moorhens used a wide variety of habitat types as also noted by Anfinnsen (1961). However, they were more often present, and also had higher occupancy rates, at some types of dammed ponds (in particular farm ponds, park ponds and ice ponds) than at natural waterbodies. Analyses of how occupancy and occupancy rate was related to the four different site variables indicated that depending on type of analysis, all variables appeared to have some effect. Thus, the most suitable sites for Moorhens appear to be small wetlands at low elevation close to the coast with a high nutrient level. However, it should be noted that most analyses had a rather low predictive power (low proportion of the variance explained). For all variables there was large overlap between occupied and unoccupied sites (Figure 4), and there was a large amount of variation in occupancy rate in relation to site variables (Figure 5). Furthermore, although there were no serious collinearity problems (all variance inflation factors $(\mathrm{VIF}) \leq 3.0$ ), significant relationships between some of the explanatory variables were present. In particular, distance from the coast and elevation were positively correlated $\left(\mathrm{r}^{2}=\right.$ $0.64)$. When different predictors are strongly correlated to the response variable on their own, and correlated with each other, their relative importance may vary in models with several predictors at the same time. This may explain why different models yielded different significant predictors. In conclusion, it appears that all four site variables have some influence on site use by Moorhens, but their magnitude depends on type of comparison made (occupied versus unoccupied, occupancy rate) and variables included (with or without nutrient level). Analyses that included nutrient level had much smaller sample size (data available for only about one third of the sites), and may also represent biased samples because collection of data on nutrient level was done by other researchers and for different purposes than my study. The relative importance of the other three site variables (wetland size, distance from coast, elevation) may therefore best be judged from models not including nutrient level. In those cases, wetland size (analysis of occupancy rate) and elevation (analysis of occupancy) appeared to be most important.

\section{Conservation status and management recommendations}

In Oslo and Akershus, the Moorhen has a population size not very different from previous estimates, and there were no large population changes during the period 1995-2018. The results may suggest that the population size in Norway is larger than previously thought (perhaps 300 pairs compared to 110-215 pairs estimated by Shimmings \& Øien 2015), but this does not affect red list status because in both cases the population falls within 250-1000 reproductive individuals. Overall, this suggests that the previous red listing as vulnerable (Kålås et al. 2015) was reasonable. Populations in Sweden and Finland are also relatively small [Sweden: 3100 pairs and stable (Ottosson et al. 2012, Green et al. 2020); Finland: 50-200 pairs and stable (Väisänen et al. 2011)]. Thus, the potential for recolonization from other countries in case of local extinctions is likely low. The persistence of the Norwegian population will therefore depend on continued availability and high quality of breeding sites in order to have a self-sustaining population.

The Moorhen has recently shown ability to colonize some new habitats in Oslo and Akershus. With increasing focus on managing wastewater (e.g. Skaara 2015), the creation of more filtering ponds is likely. On the other hand, one potential threat to many sites is lack of maintenance of pond dams, and even for safety reasons there are plans to demolish some dams (Häusler 2018, Markarådet 2019). One relevant case was Østenstaddammen in Asker which was without water in 2017-2018 due to a leak in the dam. There were concerns that the pond would remain dry (Løtveit et al. 2018), but it was later restored and contained water again in 2019. For the Moorhen, it is essential that the large number of small dammed ponds around the Oslofjord are maintained and have a stable water level. In particular, ice ponds have not been of commercial interest for many years, and if authorities do not accept 
the cost of maintenance, they risk becoming damaged and drained by wear and tear, leading to a loss of breeding sites for the Moorhen.

Acknowledgements. I thank the Environmental Authorities of Oslo and Akershus County for financial support, Ronny Steen for help with rtrim-analyses, and Terje Lislevand and one anonymous reviewer for comments on the manuscript.

\section{REFERENCES}

Anfinnsen, M.T. 1961. Sivhøna, Gallinula chloropus (L.) i Norge. Utbredelse og rugeforhold. Sterna 4: 345-377. (In Norwegian)

Bogaart, P., van der Loo, M. \& Pannekoek, J. 2018. rtrim: Trends and Indices for Monitoring Data. R package version 2.0.6.

Dale, S., Andersen, G.S., Eie, K., Bergan, M. \& Stensland, P. 2001. Guide til fuglelivet i Oslo og Akershus. Norsk Ornitologisk Forening, Oslo og Akershus. (In Norwegian)

Gjershaug, J.O., Thingstad, P.G., Eldøy, S. \& Byrkjeland, S. (eds.). Norsk fugleatlas. Norsk Ornitologisk Forening, Klæbu. (In Norwegian)

Green, M., Haas, F. \& Lindström, A. 2020. Övervakning av fåglarnas populationsutveckling. Årsrapport för 2019. Lunds Universitet.

Haftorn, S. 1971. Norges Fugler. Universitetsforlaget, Oslo. (In Norwegian)

Häusler, J. 2018. Innspill til plan for Askers dammer. https:// naturvernforbundet.no/brev-og-uttalelser-2018/innspilltil-plan-for-askers-dammer-article38736-4030.html. (In Norwegian)

Kålås, J.A., Dale, S., Gjershaug, J.O., Husby, M., Lislevand, T., Strann, K.-B. \& Strøm, H. 2015. Norsk rødliste for arter 2015. Fugler Aves. Artsdatabanken.

Løtveit, Ø., Hansen, T., Smaaland, T., Berntsen, T. \& Morset, P. Aksjon. Naturperlen Østenstaddammen er borte, dammen lekker. https://www.budstikka.no/debatt/ dammen-ma-utbedres/21932!/. (In Norwegian)

Markarådet. 2019. Dammer i Marka. https://www. statsforvalteren.no/siteassets/fm-oslo-og-viken/miljoog-klima/markaradet/protokoller/2019/vedlegg-4--utkast-til-brev-om-dammer-til-kommunene.pdf. (In Norwegian)

Monthouel, M. \& Dale, S. 2019. Population decline of the Eurasian Curlew in Akershus, southeastern Norway. Ornis Norvegica 42: 19-27.

Olsen, O. 1982. Hekkende våtmarksfugl i Oslo og Akershus. Toppdykker'n 5: 5-34. (In Norwegian)

Ottosson, U., Ottval, R., Elmberg, J., Green, M., Gustafsson, R., Haas, F., Holmqvist, N., Lindström, A., Nilsson, L., Svensson, M., Svensson, S. \& Tjernberg, M. 2012. Fåglarna i Sverige - antal och förekomst. Sveriges Ornitologiska Förening, Halmstad.

Shimmings, P. \& Øien, I.J. 2015. Bestandsestimater for norske hekkefugler. Norsk Ornitologisk Forening, rapport 2-2015. (In Norwegian)

Siegel, S. \& Castellan, N.J. 1988. Nonparametric statistics for the behavioral sciences. McGraw-Hill. New York.

Skaara, T. 2015. Hvordan kan rensedammer utformes langs landeveien slik at tekniske, estetiske og økologiske hensyn blir ivaretatt. Case E-18 Vestfold. Master Thesis, Norwegian University of Life Sceinces. (In Norwegian)

Väisänen, R.A., Hario, M. \& Saurola, P. 2011. Population estimates of Finnish birds. In: Valkama, J., Vepsäläinen, V. \& Lehikoinen, A. 2011. The Third Finnish Breeding Bird Atlas. Finnish Museum of Natural History and Ministry of Environment (http://atlas3.lintuatlas.fi/english).

Økland, J. \& Økland, K.A. 1998. Vann og vassdrag 3. Kjemi, fysikk og miljø. Vett \& Viten, Nesbru. (In Norwegian)

Øien, I.J. 1994. Sivhøne Gallinula chloropus. Pp. 160-161 in: Gjershaug, J.O., Thingstad, P.G., Eldøy, S. \& Byrkjeland, S. (eds.). Norsk fugleatlas. Norsk Ornitologisk Forening, Klæbu. (In Norwegian)

Received 02.10.2020. Accepted 15.02.2020 